\title{
О.В. Полохин
}

\section{ОСНОВНЫЕ ЧЕРТЫ СТРОЕНИЯ И ГЕНЕЗИСА ПОЧВ ОСТРОВА УРУП}

Почвы острова Уруп остаются малоизученными. Связано это с труднодоступностью, неустойчивой погодой и практически необитаемостью большей части острова $[5,7]$. Цель работы заключалась в выявлении основных морфологических особенностей, физических и физико-химических свойств почв центральной части о. Уруп.

Исследования проводились в августе 2015 году в центральной части. Это прибрежная территория рейда Открытый, в районе протоки соединяющей озеро Токотан с Охотским морем. При проведении полевых исследований были заложены две площадки размером 10х10м на различных элементах ландшафта. Первая пробная площадка была заложена в средней части прибрежного склона озера Токотан напротив перешейка Токотан, а вторая площадка на береговом песчаном валу. На учетных площадках были заложены почвенные разрезы и выполнено по 4 прикопки. Образцы почв для анализов отбирались по общепринятым методикам. В полевых условиях описывались морфологические признаки почв и отбирались образцы для лабораторных исследований, описывался видовой состав растительности. В образцах измерялись рНводный потенциометрическим методом [1]. Плотность сложения определялась буровым методом [1]. Определение каменистости выполнено весовым методом. Валовое содержание основных оксидов определялось на рентгенофлюорисцентном спектрометре Shimadzy EDX 800 (Япония).

В группе южных островов Курильского архипелага остров Уруп является самым северным. Он входит в число четырех наиболее больших островов гряды. Остров представляет собой слившиеся подножием вулканы. [4].

На острове Уруп распространен вулканно-тектонический рельеф с отдельными вулканическими постройками или массивами, расположенными на поднятом на разную высоту до- четвертичном складчатом основании $[2,3]$. На о. Уруп широко развита гидрографическая сеть, состоящая из множества ручьев, небольших рек, озер, болот и водопадов. Река Токо- 
тан и озеро с одноименным названием, которые находятся в районе исследования относятся к наиболее крупным на острове.

Согласно климатическому районированию о. Уруп входит в средний климатический район Курильских островов и характеризуется прохладным летом и достаточно многоснежной и мягкой зимой. Район исследования находиться на охотоморской стороне острова и отделен от тихоокеанской части высокими хребтами Криштофовича и Петра Шмидта и в теплый период времени, когда преобладают ветры юго-восточного направления, приносящие туманы на тихоокеанское побережье острова на охотоморской части побережья значительно больше солнечных дней, выше солнечная инсоляция. Среднегодовое количество осадков составляет 1015-1230 мм. Большая часть осадков (около 65\%) выпадает в теплый период. По значениям показателя увлажненности территория острова переувлажнена. Среднегодовая температура около $+2,5^{\circ} \mathrm{C}$ (средняя по островам). Безморозный период около 225 дней, вегетационный период составляет 130-140 дней.

Согласно ботанико-географическому районированию о. Уруп относится к Восточноазиатской флористической области Урупскому флористическому району Южно-Курильского округа Сахалино-Хоккайдской провинции [2].

По почвенно-географическому районированию о. Уруп входит в состав Урупского района Среднекурильского округа Сихотэ-АлинскоСахалинской провинции [7]. По данным Н.М. Костенкова и В.И. Ознобихина [8] основными почвами Урупа являются охристые типичные - 51,5\% от площади острова, охристо-подзолистые - 20,3\%, сухоторфяные океанические - 10,9\%, литоземы перегнойно грубогумусовые $-6,3 \%$.

Учетная площадка Р У 1-15 (4551'38.27"C 14947'44.59"В). Расположена на юго-западном склоне г. Рудакова, уклон $30^{\circ}$, высота над уровнем моря 41 м, 510 м от рейда, 300 м от западной части озера Токотан. Склоны покрыты широкими и глубокими ложбинами. В составе пород преобладают андезито-базальтовые и андезитовые лавы с чередованием лавопирокластических и пирокластических отложений (вулканических туфов) [6]. Склон покрыт древесно-кустарниково-луговой растительностью. Древесно-кустарниковые представлены березой Эрмана, рябиной бузинолистной, тисом остроконечным и стлаником кедровым. Среди трав в период исследований преобладали лабазник камчатский, саза куриль- 
ская, какалия мощная. Проективное покрытие 100\%. Строение почвы можно проиллюстрировать следующим разрезом.

АО 0-1см опад, состоящий из неразложившихся листьев, стеблей травянистых растений.

Ад 1-7 см дернина, состоящая из переплетенных живых и отмерших малоразложившихся растительных остатков корней травянистых и кустарниковых растений, темно-серый с буроватым оттенком, окраска однородная неравномерная, сырой, мажется, рыхлый, непрочно-мелкокомковатый порошистый, опесчаненный легкий суглинок, граница волнистая, упругий, переход ясный.

ВН 7-22 см бурый, влажный, слабо выраженное явление псевдо тиксотропии, непрочно-комковато порошистый, рыхлый, плотнее предыдущего, включение легких светло-бурых «камней» 5-60 мм, корней много, переход заметный, граница волнистая.

2А 22-40 см темно-бурый неоднородный по цвету, влажный, включения светлых камней 5-70 мм, много живых корней, переход заметный, граница волнистая.

2ВН 40-65 см, темно-бурый с рыжеватым оттенком неоднородный, темнее предыдущего, мокрый, включения камней.

Дальнейшее углубление разреза затруднено из-за высокого содержания камней. В валовом составе отмечается высокое содержание полуторных оксидов (с максимумом 23\% и 14\% соответственно на глубине 25-60 см), уменьшение вглубь по профилю содержания оксида кремния и высокое содержание валового фосфора. Это позволяет отнести данный тип почвы к охристым. На данном этапе исследования мы диагностируем тип данной почвы как дерново-перегнойная среднемощная (охристая?) вулканическая.

Учетная площадка Р У 2-15 (4551'34.64"C 14947'7.91"В). Расположена на береговом песчаном валу шириной около 25 м, высота 4 м, в 87 м от уреза воды. Кустарниковая растительность представлена шиповником морщинистым, среди травянистой растительности преобладает колосняк мягкий. Остальная растительность представлена сазой, бобовыми, полынью, осокой и вейником. Проективное покрытие 95-100\%. Морфологические особенности строения почвы на данной площадке показаны следующим разрезом.

АО 0-1 см опад, состоящий из не разложившихся стеблей и листьев травянистых растений. 
АдА 1-46 темно-серый, неоднородно слоистый по окраске, чередуются светло- и темно-серые слои, густые живые корни, песчаный, влажный, уплотнен, граница слабо волнистая переход заметный по цвету и плотности.

АВ 46-78 неоднородный по окраске от серого до темно серого, но более светлого, чем вышележащий слои, песчаный, влажный, более плотный, чем предыдущий, в верхней части много корней в нижней мало. Почва дерновая слоисто-песчаная.

По плотности сложения почва на площадке Р У 1-15 относится к вспушенным, богатым органическим веществом. Средне профильная плотность составляет 0,66 г/ $\mathrm{cm}^{3}$ (табл. 1). Диапазон колебаний составляет $0,38-0,72$ г/ $\mathrm{cm}^{3}$.

При этом погребенный гумусово-аккумулятивный горизонт имеет плотность сложения меньшую, чем ниже и выше расположенные. Каменистость вниз по профилю возрастает, причем с глубины 22-40 см резко до значений 40-50\%.

Почва морской террасы по показателям плотности сложения соответствует уплотненным и сильно уплотненным.

Измерения рНводн. показывают, что почвы на учетной площадке под древесно-кустарниково-луговой растительностью более кислые, чем на морской террасе под прибрежной растительностью. По значениям актуальной кислотности их можно отнести к почвам с кислой реакцией сре-

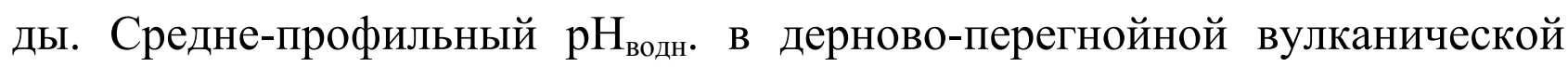
почве составил 4,88. Амплитуда колебаний для $\mathrm{pH}_{\mathrm{H} 2 \mathrm{O}}$ от 4,75 до 5,05. При этом наибольшая профильная разница по этому показателю составляет 0,3 (разница $<0,5$ ), что позволяет отнести данный тип почвы к кислотнонедифференцированным. Это связано с видовым составом растительности и соответственно с качеством растительного опада. Кроме того, возможно на кислотно-основные свойства данного типа почв оказывают влияние большое количество осадков, низкие температуры в теплый период и в определенной степени свойства материнских пород.

Дерново-слоистые песчаные почвы имеют более высокие показатели

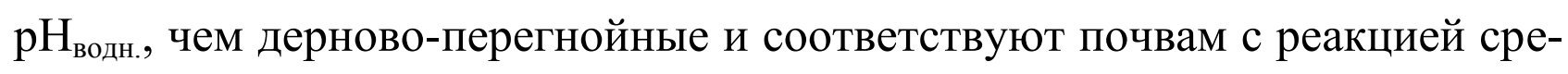
ды от слабо-кислой до близкой к нейтральной. Значение средне профильного $\mathrm{pH}_{\mathrm{H} 2 \mathrm{O}} 6,63$ (близкие к нейтральным $>6,0$ ). По величине наибольшей профильной разности $\mathrm{pH}_{\mathrm{H} 2 \mathrm{O}}(0,7)$ почва может быть отнесена к кислотно- 
слабодифференцированной (в пределах 0,5-1). Такие значения актуальной кислотности, возможно, связаны с близостью вод Охотского моря имеющих достаточно высокую щелочность.

Таким образом, под древесно-кустарниково-луговой растительностью сформировались дерново-перегнойные вулканические среднемощные почвы. На морской террасе под прибрежной растительностью развиты дерново-слоистые песчаные почвы. Почвы на круто склоновых поверхностях имеют укороченный профиль с резко возрастающей каменистостью вниз по профилю. Наличие погребенных горизонтов свидетельствует о крупных извержениях вулкана Рудакова. Отсутствие видимых прослоек пеплов позволяет говорить о том, что район исследования длительное время находится в зоне слабых пеплопадов. Морфологическое строение почвенного профиля этих почв подтверждает, что почвообразование имеет синлитогенный (вулканогенный) характер. Кислотноосновные свойства почв на склонах в большой степени зависят от биогенного и климатогенного факторов. Почвы кислотно-недифференцированы. Можно предположить, что актуальная кислотность почв морской террасы зависит от удаленности от вод Охотского моря.

\section{Литература}

1. Агрохимические методы исследования почв. - М.: Наука, 1975. $656 \mathrm{c}$.

2. Баркалов В.Ю. Флора Курильских островов /В.Ю. Баркалов. Владивосток: Дальнаука, 2009. - 468 с.

3. Ганзей К.С. Ландшафты и физико-географическое районирование Курильских островов: дис. ... канд. геогр. наук. - Владивосток, 2009. - 161 с.

4. Горшков Г.С. Вулканизм Курильской островной дуги /Г.С. Горшков. - М.: Наука, 1967. -287 с.

5. Егорова Л.Н., Полохин О.В., Щапова Л.Н., Ковалева Г.В., Сибирина Л.А. Структура сообществ микромицетов в вулканических почвах острова Симушир (Курильский архипелаг) //Вестник Дальневосточного отделения Российской академии наук. - 2015. - № 5 (183). - С. 35-39.

6. Камчатка, Курильские и Командорские острова / Отв. ред. И.В. Лучицкий. - М.: Наука, 1974. - 528 с. 
7. Костенков Н.М., Ознобихин В.И. Почвенно-географическое районирование Курильских островов //Вестник СВНЦ ДВО РАН. - 2011. - №1. C.77-83.

8. Костенков Н.М., Ознобихин В.И., Шляхов С.А. Почвы // Атлас Курильских островов. - М.: ИВЦ «ДИК», 2009. - С. 61-68.

9. Полохин О.В., Сибирина Л.А. Почвенный и растительный покров острова Итуруп (Курильские острова) // Современные проблемы науки и образования. - 2014. - № 5. - С. 618.

10. Полохин О.В., Сибирина Л.А. Почвы и растительность острова Симушир (Курильские острова) //Фундаментальные исследования. - 2013. № 10 (часть 8). - С. 1766-1769. 